\title{
Cell Cycle-dependent Interleukin 1 Gene Expression by Cultured Glomerular Mesangial Cells
}

\author{
David H. Lovett* and Alf Larsen ${ }^{\star}$ \\ ${ }^{*}$ Medical Service, Veterans Administration Medical Center-University of California, San Francisco, San Francisco, California 94121 ; \\ and ${ }^{\ddagger}$ Department of Molecular Biology, Immunex Corporation, Seattle, Washington 98101
}

\begin{abstract}
Glomerular mesangial cell (MC)-derived IL-1 may be an important factor in the development of the hypercellularity and sclerosis characteristic of many forms of glomerulonephritis. To define the regulation of IL-1 synthesis by human MC, Northern blot analyses were performed using specific probes for monocytic IL-1 $\alpha$ and $\beta$ mRNA. Proliferating MC expressed mRNA for both IL-1 $\alpha$ and $\beta$, whereas nonproliferating MC contained no detectable IL-1 mRNA. Synchronized MC expressed IL-1 $\alpha$ and $\beta$ mRNA within $2 \mathrm{~h}$ of stimulation with serum. This serum effect could be reproduced with platelet-derived growth factor and epidermal growth factor. Immune precipitations of ${ }^{35} \mathrm{~S}$-methionine-labeled cells indicate that the mesangial IL-1 is synthesized as a 33-kD precursor protein with a pI of 7.2. Extracellular mesangial IL-1 has a pI of 7.0 and molecular weight of $17 \mathrm{kD}$, consistent with its identification as IL-1 $\beta$. Cellular proliferation in glomerular disease may be driven in part by peptide growth factor-mediated induction of mesangial IL-1 gene expression and protein synthesis.
\end{abstract}

\section{Introduction}

IL-1 represents a family of proteins that have a central function in the development of immune and inflammatory processes. Originally viewed as a product solely of activated monocytes, it is now generally recognized that molecules displaying IL-1 activity are produced by many discrete cellular types. These include glial cells, endothelial cells, keratinocytes, B cells, and glomerular mesangial cells (MC), ${ }^{1}$ among others (1-4). Biochemical characterization of the monocyte-derived IL-1 has demonstrated the existence of at least two distinct gene products, termed IL- $1 \alpha$ and IL-1 $\beta$ (5-8). Extracellular IL-1 has a molecular mass of $17 \mathrm{kD}$ and displays charge heterogeneity, with prominent species at pI 7.0 and 5.0. It has been suggested that the pI 5.0 and pI 7.0 forms of extracellular IL-1 correspond to the IL-1 $\alpha$ and IL-1 $\beta$ sequences, respectively (9). Both forms of monocyte IL-1 appear to be translated as

Address correspondence to Dr. Lovett, $111 \mathrm{~J}$ Medical Center, University of California Medical Service, San Francisco VAMC, $4150 \mathrm{Clem}$ ent St., San Francisco, CA 94121.

Received for publication 20 July 1987 and in revised form 11 December 1987.

1. Abbreviations used in this paper: EGF, epidermal growth factor; HMC, human MC; IEF, isoelectric focusing; IF, immunofluorescence; IGF-1, insulin-like growth factor-1; ITS, insulin, transferrin, selenium; MC, mesangial cell; PDGF, platelet-derived growth factor.

The Journal of Clinical Investigation, Inc.

Volume 82, July 1988, 115-122 $31-33-k D$ precursor proteins $(9,10)$. The IL-1 $\beta$ species represents the principal form of IL-1 mRNA synthesized by endotoxin-stimulated human monocytes. In contrast, human keratinocyte-derived IL-1 mRNA was found to consist primarily of the IL-1 $\alpha$ species, indicating that the type of IL-1 synthesized may be cell specific (11).

The IL-1 activity produced by cultured rat glomerular MC has been characterized at both the functional and biochemical levels. MC IL-1 stimulates IL-2 secretion from splenic lymphocytes and is active as an endogenous pyrogen $(4,12)$. Most significant may be the observation that purified MC IL-1 was found to act as an autogrowth factor for cultured MC (13). This may be of potential relevance to the development of the hypercellularity seen in many glomerular diseases. Purified rat MC IL-1 has a molecular mass of $14 \mathrm{kD}$ and displays charge heterogeneity, with pIs of 7.2, 5.0, and 4.45 (13). Because of the lack of cross-reactivity of available antibodies with the rat IL- 1 , it is not presently possible to characterize the various isoelectric species as IL- $1 \alpha$ or $\beta$ analogues.

The responsiveness of MC to various peptide growth factors, including platelet-derived growth factor (PDGF) and epidermal growth factor (EGF), has been recently documented $(14,15)$. In our own studies a relationship between IL-1 secretion and MC proliferation, a process driven by peptide growth factors, was observed (13). However, the precise kinetic patterns of MC IL-1 production and the identification of the pathologically relevant mediators of this process remained largely unexplored. Given the recent availability of specific reagents for the evaluation of the human monocytic IL-1 system, we elected to more closely define the relationships between MC activation by peptide growth factors, MC IL-1 gene expression, and IL-1 secretion.

\section{Methods}

Reagents. EGF, receptor grade, and HPLC-purified PDGF were obtained from Collaborative Research, Inc. (Waltham, MA). ITS, containing $5 \mu \mathrm{g} / \mathrm{ml}$ human transferrin, $1 \times 10^{-6} \mathrm{M}$ insulin, and $5 \mathrm{ng} / \mathrm{ml}$ selenous acid (final concentrations in medium) was obtained from the same source. Goat anti-human PDGF IgG was the generous gift of E. Raines and R. Ross, Dept. of Pathology, University of Washington. Before use, the various growth factors and antibodies were absorbed with polymixin B-Sepharose ( $100 \mu \mathrm{l}$ packed beads $/ \mathrm{ml}$ component) and were free of detectable $(<0.1 \mathrm{ng} / \mathrm{ml})$ endotoxin contamination when assessed by an amoebocyte lysate assay (the generous gift of J. L. Ryan, Yale University, New Haven, CT). All other media components were screened in a similar manner.

Establishment of human MC (HMC) cultures. Human kidney was obtained at the time of elective nephrectomy from patients with various forms of well-circumscribed renal neoplasia, and primary cultures of HMC were established from collagenase-treated glomeruli as recently reported in detail (16). The growth medium consisted of RPMI 1640 supplemented with $20 \%$ heat-inactivated FCS (Gibco, Grand Island, $\mathrm{NY}$ ), $50 \mathrm{U} / \mathrm{ml}$ penicillin, $50 \mu \mathrm{g} / \mathrm{ml}$ streptomycin, and 300 
$\mu \mathrm{g} / \mathrm{ml}$ glutamine. ITS was routinely added to all culture media. Cellular outgrowths appeared within $5 \mathrm{~d}$ and consisted of interwoven, straplike cells. Small clusters of these cells (approximately five) were picked out, replated, and grown to confluency. The cultures were subsequently rapidly expanded and uniform populations were frozen in liquid nitrogen at the fourth to sixth passages. For experiments, the cells were thawed, plated in growth medium, grown to subconfluency, and used as detailed below.

The cells were characterized as intrinsic mesangial using previously reported criteria (16-18). Immunofluorescence (IF) staining revealed prominent intracellular myosin fibrils arranged along the long axis of the cells. IF was negative for factor VIII, common leukocyte antigen, and Ia antigen. Confluent cultures were multilayered, and there was no morphologic evidence for the presence of either glomerular endothelial or epithelial cells, which grow in monolayers of polygonal cells (19). Studies of protein synthetic profiles using $\left[{ }^{3} \mathrm{H}\right]$ proline and $\left[{ }^{35} \mathrm{~S}\right]-$ methionine labeling revealed the secretion of fibronectin, thrombospondin, and collagens type I, III, IV, and V (submitted for publication). For light microscopic evaluation, the HMC were washed three times with PBS and fixed with $3.7 \%$ paraformaldehyde in PBS, $1 \mathrm{mM}$ $\mathrm{MgCl}_{2}$, and $0.1 \mathrm{mM} \mathrm{CaCl}$ for $20 \mathrm{~min}$ at room temperature. After fixation the cells were evaluated by light microscopy after Giemsa staining (Fig. 1). HMC were prepared for electron microscopy using fixation and embedding procedures previously reported in detail (20). Ultrathin sections were cut, mounted, and stained with $2 \%$ aqueous uranyl acetate and lead citrate before examination with a JEOL electron microscope (Fig. 2).

Cell synchronization. For synchronization studies the HMC were washed twice with warm PBS and incubated for 48-72 $\mathrm{h}$ in RPMI 1640 supplemented with ITS and $0.5 \%$ BSA (rest medium). Supplemental insulin and transferrin were found to be required for the maintenance of cell viability under these serum-free conditions (21), and were used without modification for these experiments. Previous studies have demonstrated that under these culture conditions MC cease to secrete significant quantities of IL-1 after 24 h (13). For stimulation studies the rest medium was removed and various combinations of peptide growth factors or serum were added as detailed below.

Preparation of HMC RNA/Northern blotting. HMC cell layers were washed twice with cold PBS, released by gentle scraping, and centrifuged at $400 \mathrm{~g}$ for $10 \mathrm{~min}$. Total RNA was extracted from the pellets by the guanidine isothiocyanate/cesium chloride method (22). Total RNA from endotoxin-stimulated human peripheral blood monocytes was prepared in the same manner (5). All RNA preparations used were free of degradation.

For Northern blot analysis, $5 \mu \mathrm{g}$ total RNA per lane was electrophoresed in $1.5 \%$ agarose gels containing formaldehyde and transferred to nitrocellulose filters. Blots were hybridized with $\left[{ }^{32} \mathrm{P}\right] \mathrm{RNA}$ probes synthesized by SP 6 polymerase as previously reported (5). The IL-1 $\alpha$ probe was transcribed from a gemini (Promega-Biotec., Madison, WI) subclone of the 660-bp Hind III-Hinc II fragment of p10 A, and the IL- $1 \beta$ probe was transcribed from a gemini subclone of the 570-bp Sac I-Pvu II fragment from p IL-1-14 (5). The histone $\mathrm{H}_{2 b}$ probe was the generous gift of $P$. Challoner (Fred Hutchinson Cancer Research Center, Seattle, WA) and was derived from a 2.3-kb Hind BIII-Bam $\mathrm{H} 1$ fragment as reported (23). After hybridization for $16 \mathrm{~h}$ at $63^{\circ} \mathrm{C}$ in Stark's buffer, the blots were washed with $0.1 \times$ standard saline citrate and autoradiographed at $-70^{\circ} \mathrm{C}$ with intensifying screens. The positions of ribosomal 28 and $18 \mathrm{~S}$ RNAs were determined by visualization of unbaked blots with short wave UV light. The Northern blots presented are representative of experiments performed using several independently derived lines of HMC.

IL-1 assay. The levels of biologically active IL-1 in the HMC supernates were quantitated in a conventional thymocyte co-mitogenesis assay. In brief, $1.5 \times 10^{6}$ thymocytes from 8-10-wk-old $\mathrm{C} 3 \mathrm{H} / \mathrm{HeJ}$ mice (Charles River Breeding Laboratories, Wilmington, MA) were cultured in $200 \mu \mathrm{l}$ RPMI 1640 supplemented with $5 \%$ FCS, $50 \mathrm{U} / \mathrm{ml}$ penicillin, $50 \mu \mathrm{g} / \mathrm{ml}$ streptomycin, $2 \mathrm{mM}$ glutamine, $1 \times 10^{-5} \mathrm{M} \beta$ mercaptoethanol, and $0.5 \mu \mathrm{g} / \mathrm{ml}$ concanavalin A. The cultures con- tained serial dilutions of test materials or serial dilutions of purified human recombinant IL- $1 \beta$ as a standard. The cultures were pulsed at $48 \mathrm{~h}$ with $1 \mu \mathrm{Ci}\left[{ }^{3} \mathrm{H}\right]$ thymidine/well $(2 \mathrm{Ci} / \mathrm{mmol}$, New England $\mathrm{Nu}-$ clear, Boston, MA) and terminated $24 \mathrm{~h}$ later using an automated cell harvester. IL-1 activity was calculated by probit analysis, in which the standard recombinant IL- $1 \beta$ at a concentration of $1 \mathrm{U} / \mathrm{ml}$ induced a $50 \%$ maximal thymocyte proliferative response under the conditions used. The protein content of trichloroacetic acid-precipitated cell layers was determined by the method of Bradford (24) using BSA as a standard.

Biosynthetic labeling/immune precipitation. Subconfluent HMC cultures were placed in rest medium for $72 \mathrm{~h}$ as detailed above. Thereafter, the rest medium was removed and the cells were incubated with methionine-deficient DME for $60 \mathrm{~min}$. This medium was then removed and replaced with fresh methionine-deficient DME containing $\left.100 \mu \mathrm{Ci} / \mathrm{ml}^{35} \mathrm{~S}\right]$ methionine $(1,350 \mathrm{Ci} / \mathrm{mmol}$, New England Nuclear $)$, PDGF at $5 \mathrm{ng} / \mathrm{ml}$, EGF at $100 \mathrm{ng} / \mathrm{ml}$, and ITS. After culture for $6 \mathrm{~h}$, the supernates were removed, centrifuged at $400 \mathrm{~g}$ for $10 \mathrm{~min}$, supplemented with protease inhibitors ( $5 \mathrm{mM}$ EDTA, $0.2 \mathrm{mM}$ phenylmethylsulfonyl fluoride, and $2 \mu \mathrm{M}$ pepstatin), and frozen at $-70^{\circ} \mathrm{C}$. The HMC cell layers were washed twice with cold PBS, scraped into microfuge tubes, and centrifuged at $1,000 \mathrm{~g}$ for $5 \mathrm{~min}$. The cell pellets were then lysed in an equal volume of two times lysis buffer consisting of (final concentrations) $2 \% \mathrm{NP}-40,0.15 \mathrm{M} \mathrm{NaCl}, 10 \mathrm{mM} \mathrm{NaH}{ }_{2} \mathrm{PO} 4$, $10 \mathrm{mM} \mathrm{Na}_{2} \mathrm{HPO}_{4}, 0.68 \mathrm{M}$ sucrose, $\mathrm{pH} \mathrm{7.2,} \mathrm{and} \mathrm{protease} \mathrm{inhibitors} \mathrm{as}$ given above. Cell lysates were incubated on ice for $30 \mathrm{~min}$, sonicated briefly, and centrifuged at $10,000 \mathrm{~g}$ for $15 \mathrm{~min}$. For immune precipitation of radiolabeled intracellular IL-1, the cell lysates were precleared by incubation at $4^{\circ} \mathrm{C}$ overnight with $10 \% \mathrm{vol} / \mathrm{vol}$ pansorbin (Calbiochem-Behring Corp., La Jolla, CA). Cleared lysates were then incubated for $18 \mathrm{~h}$ at $4^{\circ} \mathrm{C}$ overnight with a 1:20 final dilution of rabbit polyclonal anti-human IL-1 IgG (Genzyme, Boston, MA). This antibody preparation recognized both the pI 7.0 and pI 5.0 forms of monocyte IL- 1 in experiments utilizing either immune precipitation or immunoblotting (not shown). Nonimmune rabbit IgG was used as a negative control. After incubation, $10 \%$ pansorbin was added and the bound immune complexes were recovered by centrifugation. The pelleted bacteria were washed five times in 100 -fold excess volumes of buffer containing $0.5 \% \mathrm{NP}-40,0.45 \mathrm{M} \mathrm{NaCl}$, and $0.05 \mathrm{M} \mathrm{Tris} / \mathrm{HCl}, \mathrm{pH}$ 8.3. The pellets were finally resuspended in isoelectric focusing (IEF) sample buffer (9.3 $\mathrm{M}$ urea, $5 \mathrm{mM} \mathrm{K}_{2} \mathrm{CO}_{3}, 2 \% \mathrm{NP}-40$, 2\% 3-10 ampholines, and $30 \mathrm{mM}$ dithiothreitol). After a $2-\mathrm{h}$ incubation at $4^{\circ} \mathrm{C}$, the samples were centrifuged and analyzed by two-dimensional electrophoresis. Immune precipitation of radiolabeled IL-1 present in the culture supernates was performed in an identical fashion.

Electrophoretic methods. The proteins recovered by immune precipitation were analyzed by two-dimensional electrophoresis and autoradiography. IEF was performed on $0.4-\mathrm{mm}$ ultrathin polyacrylamide slabs according to Goldsmith et al. (25), using 1.4\% 4-6 ampholines and 0.6\% 3-10 ampholines (LKB, Bromma, Sweden). Focused proteins were separated in the second dimension on $12.5 \%$ SDS-PAGE discontinuous gels precisely according to O'Farrell (26). After electrophoresis the gels were fixed in $10 \%$ TCA $/ 30 \%$ ethanol for $45 \mathrm{~min}$. Fixed gels were washed twice in 5\% TCA/30\% ethanol, soaked in Enhance (New England Nuclear), and dried under heat and vacuum. Autoradiography was performed at $-70^{\circ} \mathrm{C}$ using preflashed Kodak X-O-Mat film with intensifying screens. $\mathrm{pI}$ were determined from the migration patterns of stained standard proteins (IEF calibration kit, pI 3 to 10 range; Pharmacia Fine Chemicals, Piscataway, NJ). Phosphorylase b (94 kD), bovine serum albumin (67 kD), ovalbumin (45 kD), trypsin inhibitor (20 kD), and lactalbumin (14 kD) were used as molecular mass standards for SDS-PAGE.

\section{Results}

The cells used in these studies were homogeneous and representative of the intrinsic glomerular MC, which resembles in 


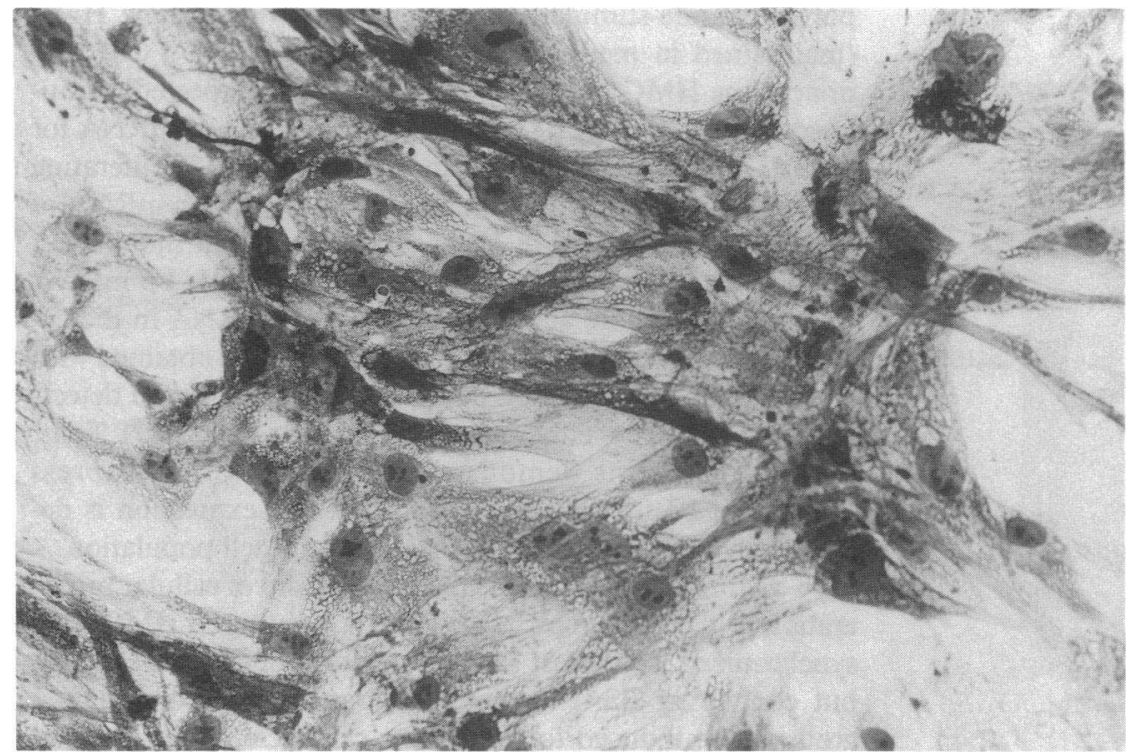

Figure 1. Light micrograph of cultured HMC. Giemsa stain. Cells have stellate or fusiform shape and grow in interwoven bundles. $\times 600$. many respects the vascular smooth muscle cell (27). As seen in Fig. 1, the cultured HMC are straplike in shape, with a prominent intracellular fibrillar component. As with rat MC, cultured HMC tend to grow in multilayers and produce abundant extracellular matrix. These features are also appreciated by transmission electron microscopy (Fig. 2). The cells display peripherally located heterochromatin and have an elongated morphology. Prominent rough endoplasmic reticulum and Golgi apparatus are present. In areas, large accumulations of extracellular matrix were noted. These features are character-

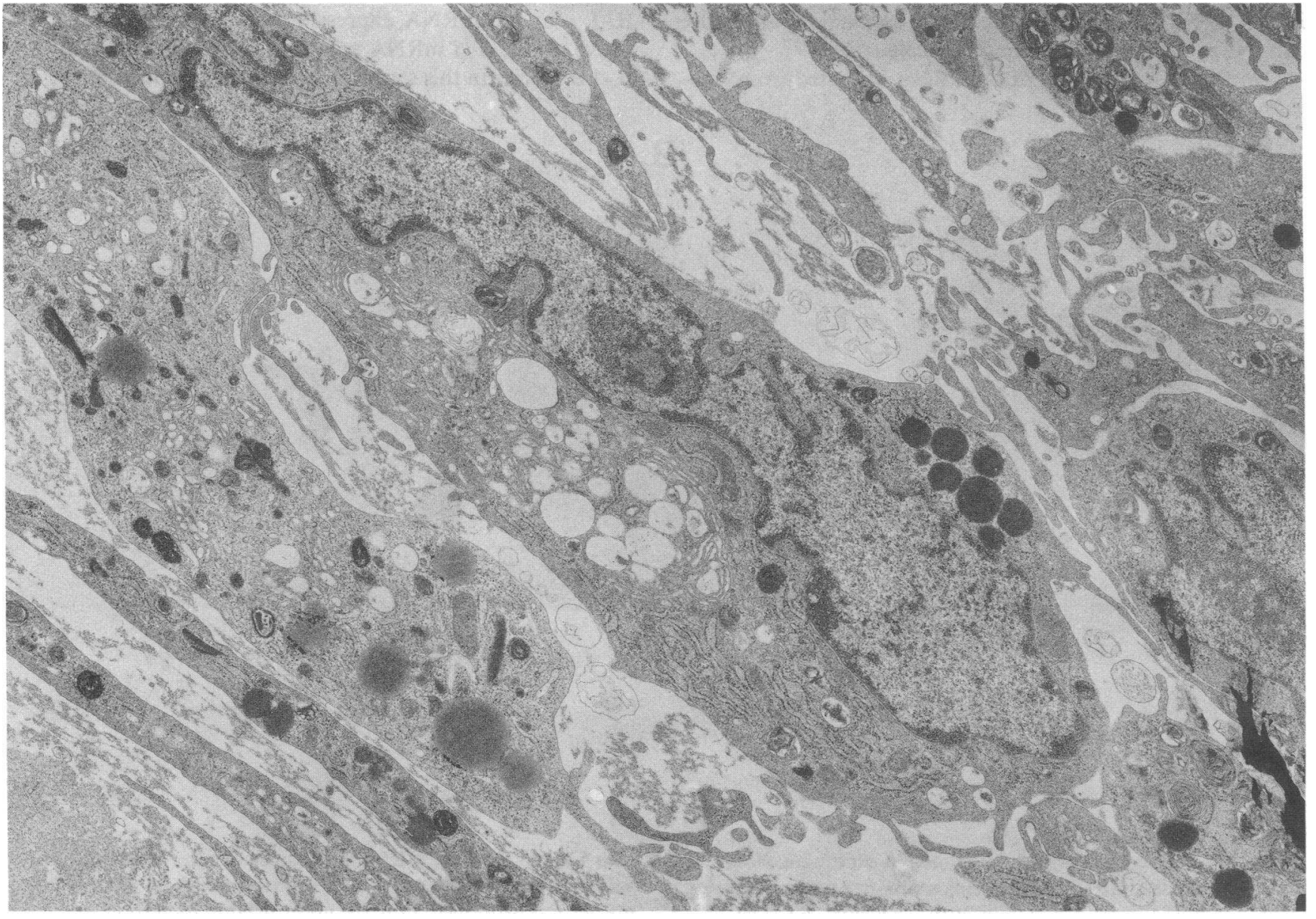

Figure 2. Electron micrograph of cultured HMC. Cells are present in multilayers with an axially elongated morphology. HMC contain peripherally condensed nuclear chromatin, prominent Golgi apparatus, and abundant rough endoplasmic reticulum. $\times 8,400$. 
A

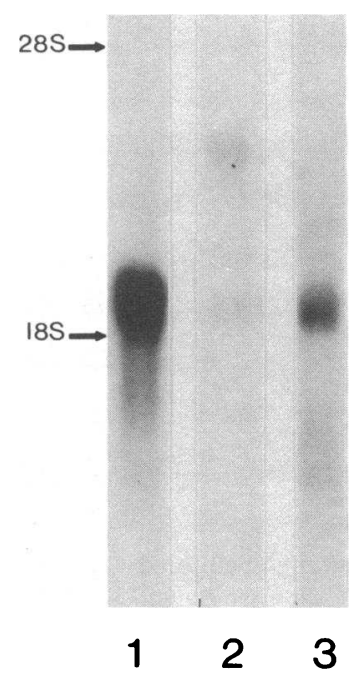

B

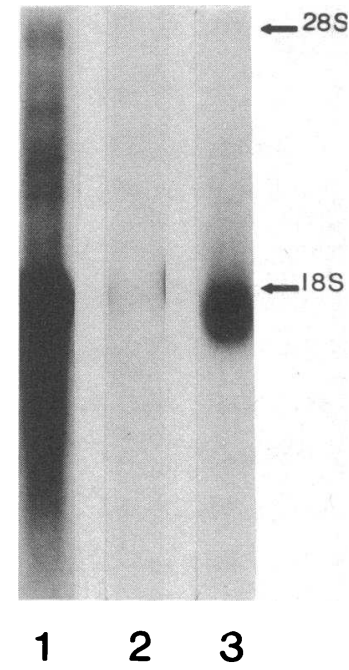

Figure 3. Northern blot analysis of RNA samples extracted from endotoxin-stimulated monocytes (lanes $A 1$ and $B 1$ ), noncycling HMC (lanes $A 2$ and $B 2$ ), and cycling HMC (lanes $A 3$ and $B 3$ ). Aliquots of total RNA $(5 \mu \mathrm{g})$ were electrophoresed, transferred, and analyzed with ${ }^{32} \mathrm{P}$-labeled probes specific for human monocyte IL-1 $\alpha(A)$ and Il-1 $\beta$ mRNA $(B)$. The positions of the $28 \mathrm{~S}$ and $18 \mathrm{~S}$ ribosomal subunits are given by the arrow markers.

istic of the intrinsic MC and exclude contamination of the cultures by endothelial or monocytic cells.

Northern blot analysis of total RNA extracted from lipo- polysaccharide-stimulated monocytes, actively cycling HMC (maintained in medium supplemented with 20\% FCS), and noncycling HMC was performed (Fig. 3). As expected, stimulated human monocytes contain large amounts of mRNA for both IL-1 $\alpha$ and $\beta$ species (lanes $A 1$ and $B 1$ ). Proliferating HMC (lanes $A 3$ and $B 3$ ) were also found to contain mRNA of both IL-1 species, but in lesser abundance than monocytes. Densitometry of autoradiograms indicated that IL- $1 \beta$ mRNA was $\sim 10$-fold more abundant than IL- $1 \alpha$ mRNA in the cycling HMC population. In contrast to the results obtained with proliferating HMC, noncycling HMC had little or no detectable IL-1 mRNA of either type (Fig. 3, lanes $A 2$ and B2). Thus, these experiments demonstrated that HMC can express mRNA for both IL-1 species, and that this expression is dependent upon the proliferative status of the cell population.

To more closely examine the relationship of cellular proliferation to the expression of IL-1 mRNA, cultured HMC were synchronized into a rest state in medium deficient of serum, but containing BSA, insulin, and transferrin. Experimental groups were induced to reenter the cell cycle by exposure to complete medium containing $20 \%$ FCS. Controls were given fresh medium devoid of serum. As seen in Fig. $4 A$, these resting cells do not express detectable quantities of IL-1 mRNA, confirming the findings shown above in Fig. 3. When resting cells were exposed to $20 \%$ serum (Fig. $4 \mathrm{~B}$ ), there appeared a time-dependent expression of both IL-1 $\alpha$ and $\beta$ mRNA. $2 \mathrm{~h}$ after serum exposure both IL-1 mRNA species were detectable; however, the subsequent kinetic patterns of IL- $1 \alpha$ and $\beta$ mRNA expression were different. As noted above, the IL- $1 \beta$ mRNA species is more abundant that the IL $-1 \alpha$ species in this serum-stimulated cell population.

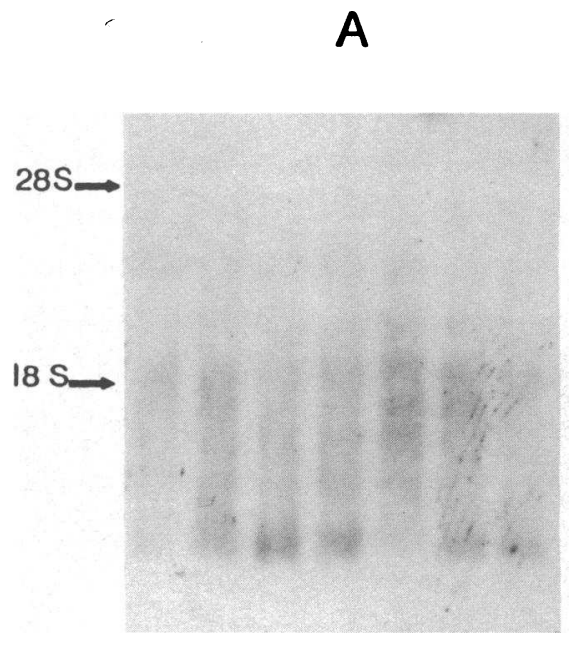

$\begin{array}{lllllll}.5 & 1 & 2 & 4 & 6 & 12 & 24\end{array}$

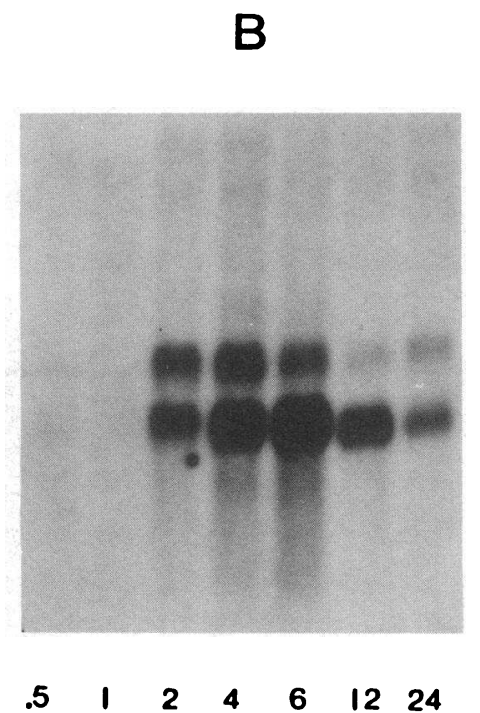

B

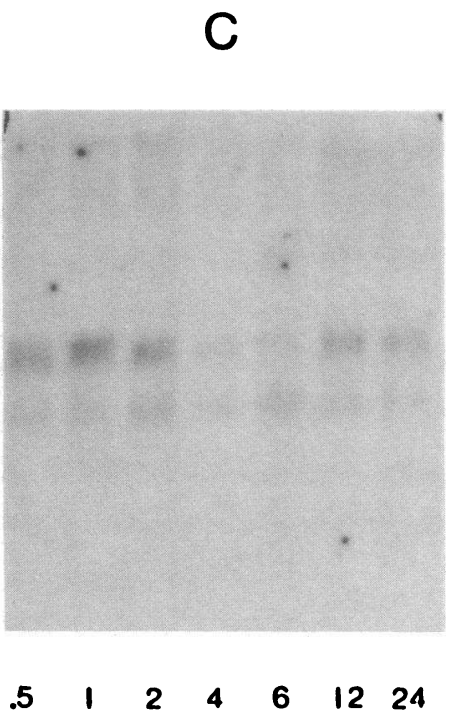

\section{TIME ' $h$ '}

Figure 4. Kinetic pattern of HMC IL-1 mRNA expression. HMC were synchronized into a rest state using serum-free medium supplemented with BSA, insulin, and transferrin. Thereafter, the HMC were incubated with either fresh rest medium $(A)$, with medium supplemented with $20 \% \mathrm{FCS}(B)$, or with rest medium supplemented with $5 \mathrm{ng} / \mathrm{ml}$ PDGF $(C)$. RNA was extracted at the given time intervals and Northern blot analysis for expression of Il-1 $\alpha$ and Il-1 $\beta$ mRNA was performed. In $B$, the upper hybridization band represents Il-1 $\alpha$ mRNA, while the lower band represents Il-1 $\beta$ mRNA. 
While serum stimulation of resting HMC allowed further definition of the cell cycle-dependent nature of IL-1 gene expression by HMC, we wished to define a minimal combination of relevant peptide growth factors that could reproduce this serum effect. Previous studies have demonstrated that PDGF is one of the major mesangial mitogens $(14,18)$. In addition, the mitogenic effect of EGF on MC has been recently reported (15). Therefore, the effects of various combinations of PDGF and EGF on IL-1 mRNA expression were examined using mitogenically relevant concentrations (references 14 and 15, and unpublished observations). When resting HMC were exposed to $5 \mathrm{ng} / \mathrm{ml}$ purified PDGF, only minimally detectable levels of IL-1 mRNA of either type were noted (Fig. $4 C$ ). EGF, at $100 \mathrm{ng} / \mathrm{ml}$, also failed to induce IL-1 mRNA expression (Fig. $5 \mathrm{~A}$ ). When these same concentrations of PDGF and EGF were used together, a time-dependent expression of IL-1 mRNA for both $\alpha$ and $\beta$ were observed (Fig. $5 B$ ). As with serum stimulation, the purified peptide growth factors appear to induce significantly more IL-1 $\beta$ than IL-1 $\alpha$ mRNA. In addition, the kinetic patterns of mRNA expression for these two species do not appear to be identical. As a control for the specificity of PDGF action in IL-1 gene expression, resting HMC were treated with the same concentrations of PDGF and EGF in the presence of $50 \mu \mathrm{g} / \mathrm{ml}$ goat anti-PDGF IgG (Fig. 5 $C)$. Inclusion of specific anti-PDGF antibodies reduced the expression of IL-1 mRNA of either type to undetectable levels.

Expression of mRNA for the S-phase-specific histone $\mathrm{H}_{2 b}$ (23) was used as a marker for peptide growth factor induction of cellular proliferation and to localize IL-1 mRNA expression to a specific portion of the cell cycle (Fig. 6). Resting HMC exposed to either PDGF (Fig. $6 \mathrm{~A}$ ) or EGF (Fig. $6 \mathrm{~B}$ ) alone expressed low, constant levels of $\mathrm{H}_{2 b}$ mRNA. After combined exposure to PDGF and EGF (Fig. $6 C$ ), enhanced $\mathrm{H}_{2 \mathrm{~b}}$ mRNA expression was noted at 12 and $24 \mathrm{~h}$, indicating onset of cellular proliferation. This pattern of histone mRNA expression helps to localize the initiation period of IL-1 mRNA expression to the $G_{1}$ phase of the cell cycle. The pattern of histone $\mathrm{H}_{2 b}$ mRNA expression, which does not mirror IL-1 mRNA expression, also demonstrates that the increase in IL-1 mRNA levels observed is not simply due to generalized increases in mRNA transcription rates.

To correlate IL-1 mRNA expression with synthesis of a functional IL-1 molecule(s), the amounts of biologically active material in culture supernates were quantified. For these experiments, resting HMC were stimulated with PDGF (5 $\mathrm{ng} / \mathrm{ml})$ and EGF $(100 \mathrm{ng} / \mathrm{ml})$ in the presence of insulin and transferrin. Media conditioned for discrete time intervals after growth factor stimulation were harvested and biologically active IL-1 quantified in the standard murine thymocyte assay. These results are shown in Fig. 7. Biologically active IL-1 was released in the culture medium during a limited time period of 2-6 $\mathrm{h}$ after growth factor stimulation.

The biochemical properties of the HMC IL-1 activity induced by growth factor stimulation were assessed by immune precipitation and two-dimensional electrophoretic analysis of $\left[{ }^{35} \mathrm{~S}\right]$ methionine-labeled material. For these experiments a polyclonal anti-human monocyte IL-1 preparation was used to recover the intracellular and extracellular forms of HMC

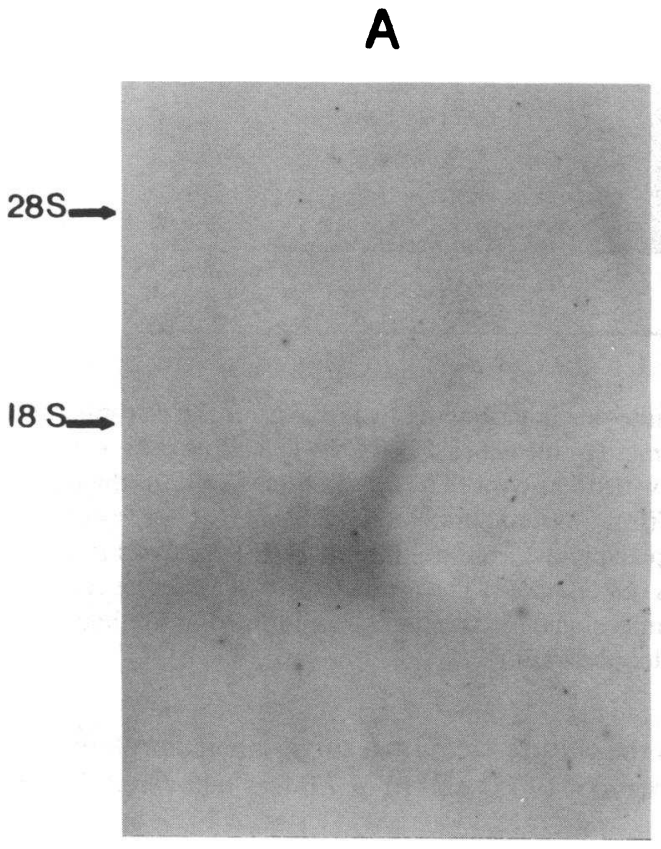

$\begin{array}{llllllll}0 & .5 & 1 & 2 & 4 & 6 & 12 & 24\end{array}$

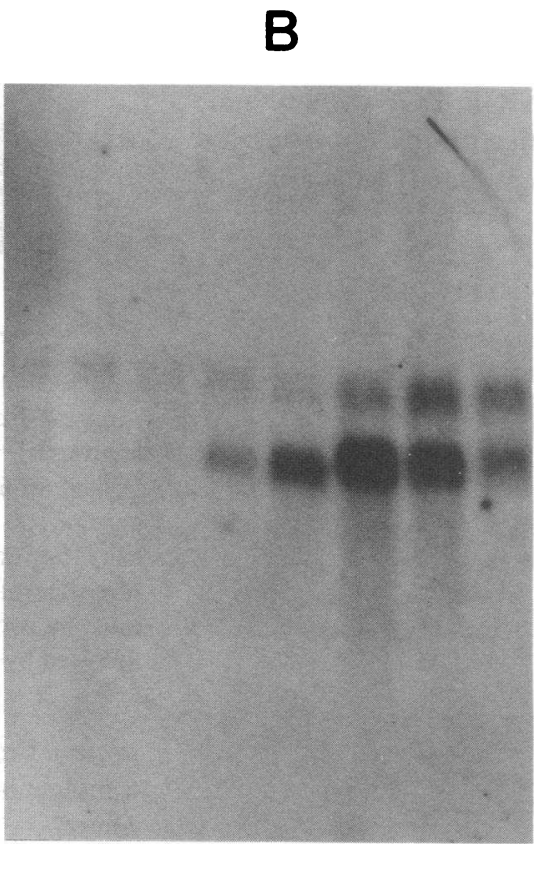

$\begin{array}{llllllll}0 & .5 & 1 & 2 & 4 & 6 & 12 & 24\end{array}$

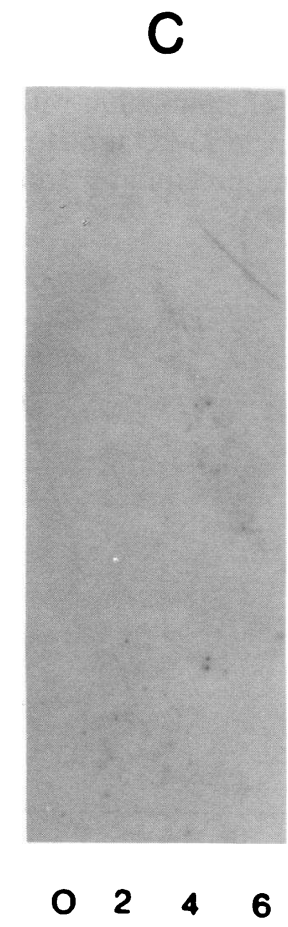

\section{TIME ' $h$ '}

Figure 5. Kinetic pattern of HMC IL-1 mRNA expression (continued from Fig. 4). The HMC were synchronized into a rest state as detailed above. The HMC were then incubated with fresh rest medium supplemented with $100 \mathrm{ng} / \mathrm{ml} \mathrm{EGF}(A)$ or with medium supplemented with 5 $\mathrm{ng} / \mathrm{ml} \mathrm{PDGF}$ and $100 \mathrm{ng} / \mathrm{ml} \mathrm{EGF} \mathrm{(B).} \mathrm{In} C$, the HMC were treated with $100 \mathrm{ng} / \mathrm{ml} \mathrm{EGF,} 5 \mathrm{ng} / \mathrm{ml} \mathrm{PDGF}$, and $50 \mu \mathrm{g} / \mathrm{ml}$ goat anti-PDGF IgG. 


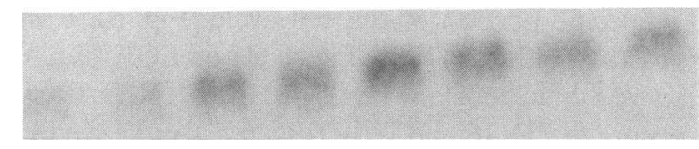

B

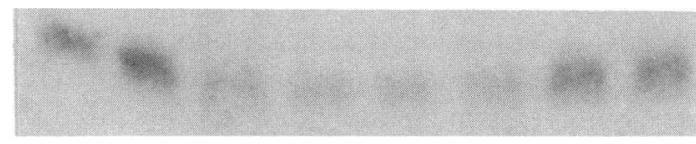

C

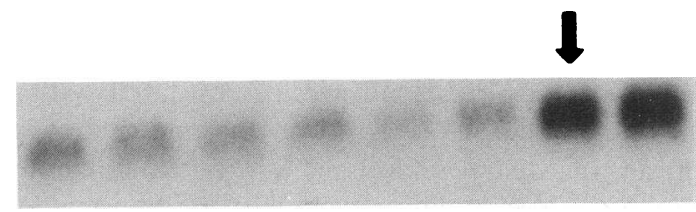

\section{$\begin{array}{llllllll}0 & .5 & 1 & 2 & 4 & 6 & 12 & 24\end{array}$}

\section{TIME ' $h$ '}

Figure 6. Kinetic pattern of S-phase specific histone $\mathrm{H}_{2 \mathrm{~b}} \mathrm{mRNA}$ expression. $(A)$ Resting cells treated with $5 \mathrm{ng} / \mathrm{ml}$ PDGF; $(B)$ resting cells treated with $100 \mathrm{ng} / \mathrm{ml} \mathrm{EGF;}(C)$ resting cells treated with 100 $\mathrm{ng} / \mathrm{ml} \mathrm{EGF}$ and $5 \mathrm{ng} / \mathrm{ml}$ PDGF. The arrow in $C$ denotes the onset of enhanced $\mathrm{H}_{2 b}$ transcription, which corresponds to the initiation of cellular DNA synthesis.

IL-1. After $6 \mathrm{~h}$ of stimulation with PDGF, EGF insulin, and transferrin, a single $33-\mathrm{kD}$ protein with a $\mathrm{pI}$ of 7.2 was detectable in immune precipitates from cellular lysates (Fig. 8,

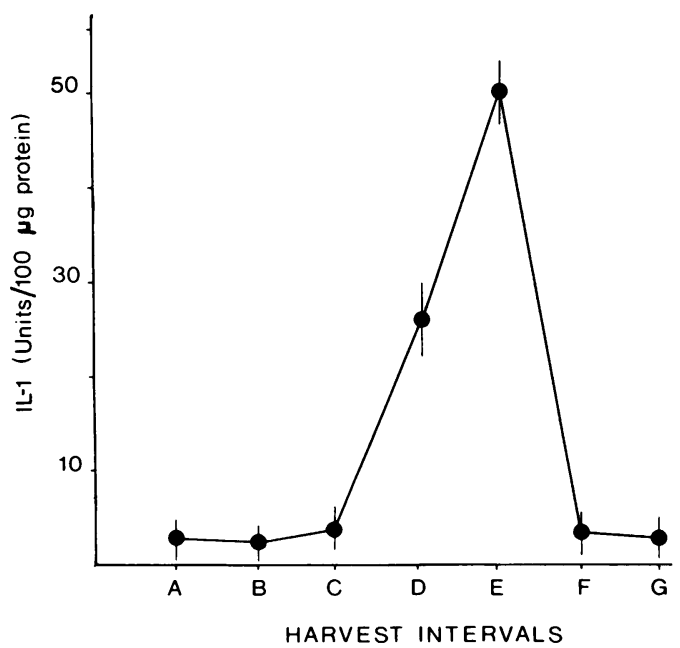

Figure 7. Temporal pattern of HMC IL-1 secretion stimulated by peptide growth factors. Resting HMC were treated with $100 \mathrm{ng} / \mathrm{ml}$ EGF and $5 \mathrm{ng} / \mathrm{ml}$ PDGF as above. HMC cultures were allowed to condition the culture media for discrete time intervals. The levels of IL-1 present in the conditioned media were determined in the thymocyte assay. Data given as mean $\pm \mathrm{SD}(n=4)$. Interval $\mathrm{A}, 0-0.5 \mathrm{~h}$; interval B, 0.5-1 h; interval C, 1-2 h; interval D, 2-4 h; interval E, 4-6 $\mathrm{h}$; interval F, 6-12 h; and interval G, 12-24 h.
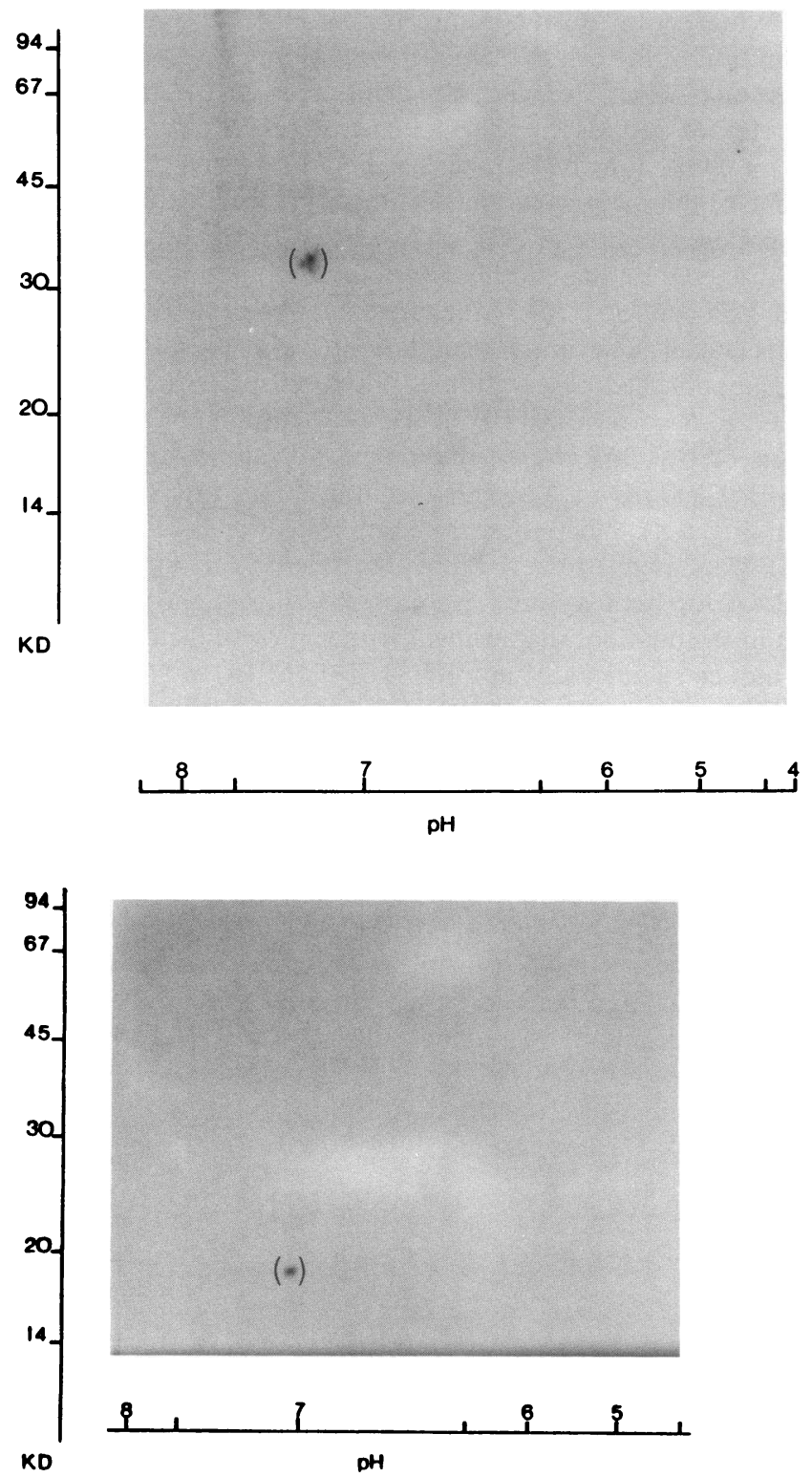

Figure 8. Immune precipitation and two-dimensional electrophoretic analysis of ${ }^{35} \mathrm{~S}$-methionine-labeled HMC IL-1. Resting cells were treated for $6 \mathrm{~h}$ with $100 \mathrm{ng} / \mathrm{ml} \mathrm{EGF}$ and $5 \mathrm{ng} / \mathrm{ml}$ PDGF in the presence of $100 \mu \mathrm{Ci} / \mathrm{ml}{ }^{35} \mathrm{~S}$-methionine. Radiolabeled IL-1 was specifcally immune precipitated from cell layers (upper panel) or the culture supernates (lower panel). The immune precipitates were separated by two-dimensional electrophoresis as outlined in Methods, followed by autoradiography.

upper). From the culture medium a single labeled protein with a molecular mass of $17 \mathrm{kD}$ and $\mathrm{pI}$ of 7.0 was recovered (Fig. 8, lower).

\section{Discussion}

Using well-characterized human glomerular MC, the expression of IL-1 mRNA and IL-1 protein synthesis was examined. Randomly proliferating HMC, in contrast to resting cells, expressed mRNA for both the IL-1 $\alpha$ and $\beta$ species. Mesangial IL-1 mRNA electrophoretically co-migrated with monocyte IL-1 mRNA, but appears to be less abundant. Serum or peptide growth factor stimulation of resting HMC resulted in a 
limited period of expression of both IL- $1 \alpha$ and $\beta$ mRNA. In each case, IL-1 $\beta$ mRNA was the predominant transcript observed. Biologically active IL- 1 was secreted into the culture medium during the period of maximal IL-1 mRNA expression. IL- $1 \beta$ mRNA expression persisted somewhat beyond the period of IL-1 protein secretion, suggesting that posttranscriptional regulatory events are involved. PGE has been recently noted to posttranscriptionally inhibit monocyte IL-1 secretion by raising intracellular cAMP levels (28). IL-1 is a potent and rapid stimulant of MC PGE secretion, (29), and it is likely that a similar form of regulation occurs in this cell type.

Immune precipitation of cellular lysates after $6 \mathrm{~h}$ of peptide growth factor stimulation in the presence of $\left[{ }^{35} \mathrm{~S}\right]$ methionine yielded a single-labeled protein with a molecular mass of 33 $\mathrm{kD}$ and $\mathrm{pI}$ of 7.2. From the culture supernates of these growth factor-stimulated cells, a single-labeled protein with a molecular mass of $17 \mathrm{kD}$ and $\mathrm{pI}$ of 7.0 was recovered. The 33-kD intracellular protein presumably represents the same precursor IL-1 protein recently described in stimulated monocytes $(9$, $10,30)$. The $17-\mathrm{kD}$ extracellular mesangial IL-1 protein closely resembles the most prominent secretory form of IL-1 derived from endotoxin-stimulated monocytes and presumably represents the IL-1 $\beta$ translation product (9). Stimulation of MC with the terminal complement components, C5b-9, also led to the release of IL-1 with a pI of 7.0, (31), suggesting that this pI species represents the major secretory form of mesangial IL-1.

The combination of a fixed concentration of PDGF and EGF in a maintenance medium containing insulin and transferrin was sufficient to induce HMC IL-1 gene expression and protein secretion. It is very probable that other combinations of peptide growth factors, or varying concentrations of these individual factors, may induce IL-1 gene expression by MC. These issues are presently under investigation. The requirement for transferrin to maintain HMC viability is common to most culture systems using serum-free media and does not suggest a specific role for transferrin in the regulation of IL-1 gene expression. MC appear to lack insulin receptors; however, specific insulin-like growth factor-I (IGF-I) receptors have been identified (32). At the supraphysiologic concentrations of insulin used in these studies $\left(1 \times 10^{-6} \mathrm{M}\right)$, insulin can bind to the lower affinity IGF-I receptors. Some IGF-I activity appears to be required to maintain HMC viability, as cultures without this concentration of supplemental insulin quickly died. As with transferrin, the requirement for insulin in the induction of IL-1 gene expression may be more related to the necessary maintenance of cellular viability than to any specific IL-1 effect.

A comparison of IL-1 gene expression and protein secretion by monocytes and other cells may provide some insights into the regulation of this factor by specific cellular types. In endotoxin-stimulated monocytes, IL- $1 \beta$ mRNA levels were detected as early as $1 \mathrm{~h}(30)$. IL- $1 \beta \mathrm{mRNA}$ levels were maximal by $6 \mathrm{~h}$, but remained elevated for at least 16-24 h after endotoxin stimulation (5, 30). IL-1 $\alpha$ mRNA was not detected at early time points (i.e., $<6 \mathrm{~h}$ ), but could be demonstrated after $24 \mathrm{~h}$ of endotoxin stimulation $(5,30)$. The kinetic pattern of monocyte IL-1 secretion generally parallels IL-1 mRNA expression and is of prolonged duration $(30,33)$. While the precise kinetic pattern was not identified, human endothelial cells were found to express exclusively IL-1 $\beta$ mRNA after $18 \mathrm{~h}$ of endotoxin stimulation (34). IL-1 $\alpha$ mRNA was observed in endothelial cells only after combined treatment with endotoxin and cycloheximide (34). A very similar pattern of IL-1 mRNA expression was observed in aortic vascular smooth muscle cells (35). The biochemical properties of secreted endothelial and vascular smooth muscle cell IL-1 have not been clearly defined, and it is presently uncertain whether these products are identical with the monocytic counterparts. The kinetic patterns of HMC IL-1 mRNA expression and protein secretion observed in these studies therefore appear to be distinctive. Our findings suggest that these events may be regulated in a cell-specific manner or that the nature of the stimulus (endotoxin vs. growth factors) may be of importance.

The involvement of the intrinsic MC is evident in most forms of glomerular disease associated with the development of sclerosis (36). The linkage between MC proliferation and matrix expansion observed at the histologic level has served as the basis for in vitro studies examining the determinants of MC growth. Recently, a relationship between cellular proliferation and augmented synthesis of mesangial matrix was demonstrated in long-term MC cultures (20). Therefore, determination of the relevant inflammatory factors that drive this proliferative process is an important experimental goal. These studies have identified PDGF and EGF as stimulants of mesangial IL-1 secretion. In glomeruli, several potential cellular sources for these growth factors are present. Platelet activation occurs frequently in glomerular inflammation and may result in the release of both PDGF and EGF (37-39). In addition, endothelial cells secrete a number of mitogens, including molecules with PDGF-like properties (40). Local release of PDGF and EGF from these sources during glomerular inflammation may represent a common mechanism whereby mesangial proliferation and matrix expansion are initiated.

\section{Acknowledgments}

The authors thank L. Chen for technical assistance and S. Gillis for a critical review of the manuscript.

This research was supported in part by grants from the Veterans Administration and the Northwest Kidney Foundation.

\section{References}

1. Fontana, A., F. Kristensen, R. Dubs, D. Gemsa, and E. Weber. 1982. Production of prostaglandin $E$ and an interleukin 1-like factor by cultured astrocytes and C6 glioma cells. J. Immunol. 129:24132419.

2. Luger, T. A., B. Stadler, B. Luger, B. Mathieson, M. Mage, J. Schmidt, and J. J. Oppenheim. 1982. Murine epidermal cell-derived thymocyte-activating factor resembles murine interleukin $1 . \mathrm{J} . \mathrm{Im}$ munol. 128:2147-2152.

3. Miossec, P., D. Cavender, and M. Ziff. 1986. Production of interleukin 1 by human endothelial cells. J. Immunol. 136:2486-2491.

4. Lovett, D. H., J. L. Ryan, and R. B. Sterzel. 1983. A thymocyte activating factor derived from glomerular mesangial cells. J. Immunol. 130:1796-1801.

5. March, C. J., B. Mosely, A. Larsen, D. P. Cerretti, G. Braedt, V. Price, S. Gillis, C. S. Henney, S. R. Kronheim, K. Grabstein, P. J. Conlon, T. P. Hopp, and D. Cosman. 1985. Cloning, sequence and expression of two distinct human interleukin 1 complementary DNAs. Nature (Lond.). 315:641-647.

6. Lomedico, P. R., U. Gubler, C. P. Hellmann, M. Dukovich, J. G. Giri, Y.-C. Pan, K. Collier, R. Semionow, A. O. Chua, and S. B. Mizel. 1984. Cloning and expression of murine interleukin-1 cDNA in Escherichia coli. Nature (Lond.). 312:458-462. 
7. Cameron, P., G. Limjuco, J. Rodkey, C. Bennet, and J. A. Schmidt. 1985. Amino acid sequence analysis of human interleukin 1. Evidence for biochemically distinct forms of IL-1. J. Exp. Med. 162:790-801.

8. Kronheim, S. R., C. J. March, S. K. Erb, P. J. Conlon, D. Y. Mochizuki, and T. P. Hopp. 1985. Human interleukin 1. Purification to homogeneity. J. Exp. Med. 161:490-502.

9. Auron, P. E., S. J. Warner, A. C. Webb, J. G. Cannon, H. A. Bernheim, K. McAdam, L. J. Rosenwasser, G. LoPreste, S. F. Mucci, and C. A. Dinarello. 1987. Studies on the molecular nature of human interleukin 1. J. Immunol. 138:1447-1456.

10. Giri, J. G., P. T. Lomedico, and S. B. Mizel. 1985. Studies on the synthesis and secretion of interleukin 1. I. A 33,000 m.w. precursor for interleukin 1. J. Immunol. 134:343-349.

11. Kupper, T. S., D. W. Ballard, A. O. Chua, J. S. McGuire, P. M Flood, M. C. Horowitz, R. Langdon, L. Lightfoot, and U. Gubler 1986. Human keratinocytes contain mRNA indistinguishable from monocyte interleukin $1 \alpha$ and $\beta$ mRNA. J. Exp. Med. 164:2095-2100.

12. Lovett, D. H., R. B. Sterzel, J. L. Ryan, and E. Atkins. 1985 Production of an endogenous pyrogen by glomerular mesangial cells. J. Immunol. 134:670-672.

13. Lovett, D. H., M. Szamel, J. L. Ryan, R. B. Sterzel, D. Gemsa and K. Resch. 1986. Interleukin 1 and the glomerular mesangium. I Purification and characterization of a mesangial cell-derived autogrowth factor. J. Immunol. 136:3700-3705.

14. Abboud, H., E. Poptic, and P. DiCorleto. 1987. Production of platelet-derived growth factorlike protein by rat mesangial cells in culture. J. Clin. Invest. 80:675-683.

15. Tsivitse, P., H. E. Abboud, C. Saunders, and T. C. Knauss. 1987. Effect of epidermal growth factor on cultured mesangial cells. Kidney Int. 31:184. (Abstr.)

16. Raugi, G., and D. H. Lovett. 1987. Thrombospondin secretion by cultured human glomerular mesangial cells. Am. J. Pathol. 129:364-372.

17. Lovett, D. H., R. B. Sterzel, M. Kashgarian, and J. L. Ryan. 1983. Neutral proteinase activity produced in vitro by cells of the glomerular mesangium. Kidney Int. 23:342-349.

18. Lovett, D. H., J. L. Ryan, and R. B. Sterzel. 1983. Stimulation of rat mesangial cell proliferation by macrophage interleukin $1 . J$. Immunol. 131:2830-2836.

19. Striker, G. E., and L. J. Striker. 1985. Biology of disease: glomerular cell culture. Lab. Invest. 53:122-131.

20. Sterzel, R. B., D. H. Lovett, H. G. Foellmer, M. Perfetto, D. Biemesderfer, and M. Kashgarian. 1986. Mesangial cell hillocks. Nodular foci of exaggerated growth of cells and matrix in prolonged culture. Am. J. Pathol. 125:130-140.

21. Libby, P., and K. V. O'Brien. 1984. The role of protein breakdown in growth, quiesscence and starvation of vascular smooth muscle cells. J. Cell. Physiol. 118:317-323.

22. Maniatis, T., E. F. Fritsch, and J. Sanbrook. 1982. Molecular Cloning. A Laboratory Manual. Cold Spring Harbor Laboratory, Cold Spring Harbor, New York. 188-209, 387-389.

23. Kreig, P. A., and D. A. Melton. 1984. Formation of the $3^{\prime}$ end of histone mRNA by post-transcriptional processing. Nature (Lond.). 308:203-206.

24. Bradford, M. 1976. A rapid and sensitive method for the quan- titation of microgram quantities of protein utilizing the principle of protein-dye binding. Anal. Biochem. 72:248-254.

25. Goldsmith, M., E. Rattner, M. Koehler, S. Balikov, and C. Bock. 1979. Two-dimensional electrophoresis of small molecular weight proteins. Anal. Biochem. 99:33-40.

26. O'Farrell, P. H. 1975. High resolution, two-dimensional polyacrylamide electrophoresis of proteins. J. Biol. Chem. 250:4007-4021.

27. Sterzel, R. B., D. H. Lovett, H. Stein, and M. Kashgarian. 1982. The mesangium and glomerulonephritis. Klin. Wochenschr. 60:10771094.

28. Knudsen, P. J., C. A. Dinarello, and T. B. Strom. 1986. Prostaglandins posttranscriptionally inhibit monocyte expression of interleukin 1 activity by increasing intracellular cyclic adenosine monophosphate. J. Immunol. 137:3189-3194.

29. Lovett, D. H., D. Gemsa, and K. Resch. 1987. Interleukin 1 and the glomerular mesangium. II. Monokine stimulation of mesangial cell prostanoid secretion. Am. J. Pathol. In press.

30. Matsushima, K., M. Taguchi, E. J. Kovacs, H. A. Young, and J. J. Oppenheim. 1986. Intracellular localization of human monocyte associated interleukin 1 (IL-1) activity and release of biologically active IL-1 from monocytes by trypsin and plasmin. J. Immunol. 136:28832891.

31. Lovett, D. H., G.-M. Hänsch, M. Goppelt, K. Resch, and D. Gemsa. 1987. Activation of glomerular mesangial cells by the terminal membrane attack complex of complement. J. Immunol. 138:24732480.

32. Conti, F. G., L. J. Striker, K. MacKay, M. A. Lesniak, J. Roth, and G. E. Striker. 1987. Mouse glomerular mesangial cells express receptors for insulin-like growth factor I but not for insulin. Kidney Int. 31:163. (Abstr.)

33. Windle, J. J., H. S. Shin, and J. F. Morrow. 1984. Induction of interleukin 1 messenger RNA and translation in oocytes. J. Immunol. 132:1317-1322.

34. Libby, P., J. M. Ordovas, K. R. Auger, L. S. Robbins, L. K. Birinyi, and C. A. Dinarello. 1986. Endotoxin and tumor necrosis factor induce interleukin 1 gene expression in adult human vascular endothelial cells. Am. J. Pathol. 124:179-186.

35. Libby, P., J. M. Ordovas, L. K. Birinyi, K. R. Auger, and C. A. Dinarello. 1986. Inducible interleukin 1 gene expression in human vascular smooth muscle cells. J. Clin. Invest. 78:1432-1438.

36. Kashgarian, M. 1985. Mesangium and glomerular disease. Editorial. Lab. Invest. 52:569-571.

37. Bowen-Pope, D. F., and R. Ross. 1984. Platelet-derived growth factor. In Clinics in Metabolism and Endocrinology: Tissue Growth Factors. W. H. Daughaday, editor. W. B. Saunders Co., Ltd., London. 191-205.

38. Bowen-Pope, D. F., and R. Ross. 1983. Is epidermal growth factor present in human blood? Alteration of EGF binding specificity in the radioreceptor assay. Biochem. Biophy. Res. Commun. 114:1036-1041.

39. Oka, Y. U., and D. N. Orth. 1983. Human plasma epidermal growth factor/ $\beta$-urogastrone is associated with blood platelets. J. Clin. Invest. 72:249-259.

40. Dicorleto, P. E., and D. F. Bowen-Pope. 1983. Cultured endothelial cells produce a platelet-derived growth factor-like protein. Proc. Natl. Acad. Sci. USA. 80:1919-1923. 